\title{
Preparation and physicochemical quality characteristics of salted kimchi cabbage using high-hydrostatic-pressure salting process
}

\author{
Eun Ji Choi ${ }^{1}$, Jeong Hyeon Lee ${ }^{1,2}$, Jae Yong Son ${ }^{3}$, Chun Wan Park ${ }^{3}$, Ho Hyun Chun ${ }^{1 *}$ \\ ${ }^{1}$ Advanced Process Technology and Fermentation Research Group, World Institute of Kimchi, Gwangju 61755, Korea \\ ${ }^{2}$ Department of Food Science and Technology, Chungnam National University, Daejeon 34134, Korea \\ ${ }^{3}$ Department of Agricultural Engineering, National Institute of Agricultural Sciences, Jeonju 54875, Korea
}

\section{초고압 절임 공정을 이용한 절임 배추 제조 및 이화학적 품질 특성}

\author{
최은지 ${ }^{1} \cdot$ 이정현 ${ }^{1,2} \cdot$ 손재용 $^{3} \cdot$ 박천완 $^{3} \cdot$ 천호현 $^{1 *}$ \\ ${ }^{1}$ 세계김치연구소 신공정발효연구단, ${ }^{2}$ 충남대학교 식품공학과, ${ }^{3}$ 국립농업과학원 농업공학부
}

\begin{abstract}
The effects of high-hydrostatic-pressure (HHP) conditions on the physicochemical quality and histological changes in kimchi cabbage (Brassica rapa L. ssp. pekinensis) during salting were investigated. The salinity and electrical conductivity of shred-type kimchi cabbage salted for $5 \mathrm{~min}$ with $15 \%$ brine at 200 MPa were $2.52 \%$ and 36.25 $\mathrm{S} / \mathrm{m}$, respectively, which were $\mathbf{2 . 8}$ and 2.3 times higher than those associated with shred-type control. The solid gain and water loss of kimchi cabbage samples during $\mathrm{HHP}$ salting increased with the $\mathrm{NaCl}$ concentration in the brine and the pressure levels, irrespective of the type of kimchi cabbage. After salting at 50 to $200 \mathrm{MPa}$, the moisture content and whiteness index of the shred-type samples were significantly $(p<0.05)$ reduced compared to those of the shred-type control. However, no significant differences $(p>0.05)$ were observed among the instrumental firmness of kimchi cabbage samples salted with 12 and $15 \%$ brines at 50, 100, and $200 \mathrm{MPa}$. During HHP salting, brine containing neutral red rapidly penetrated and stained the structurally deformed or damaged cells in the cabbage. These results indicate that the time required to prepare salted kimchi cabbage can be shortened using HHP salting.
\end{abstract}

Key words : kimchi cabbage, salting, high-hydrostatic-pressure, salinity, quality

서 론

국내 배추 총생산량 중 $90 \%$ 이상은 김치와 절임 식품 가 공에 이용되고 있다(Ku 등, 2013). 특히 절임 배추는 김치의 영양학적 특성과 품질 결정에 중요한 역할을 한다(Choi 등, 2014). 절임 중 배추 조직과 염수 사이에 삼투작용으로 배추 표피 주성분인 펙틴이 분해되고, 세포막은 파괴되면서 수용 성 물질인 비타민 C, 당류, 함황화합물과 유리 아미노산 등이
용출되면서 위해 미생물 생육은 억제된다(Lee 등, 2002). 최 근 편의성을 추구하는 소비 트렌드와 아파트 등 공동거주 형 태 증가에 따라 상품 절임 배추를 구매하여 김치를 담그는 가정이 증가하는 추세이다. 한국농촌경제연구원에서 발간한 '2017년 김장 의향 및 김장 채소 수급 전망’에 따르면 김장철 배추 원료의 구매 형태 선호는 절임 배추가 $52 \%$ 로 신선 배추 (48\%)보다 높게 나타났으며, 절임 배추는 주로 김치 제조업 체나 산지 농가를 통하여 구매하는 것으로 조사되었다.

\footnotetext{
*Corresponding author. E-mail : hhchun@wikim.re.kr, Phone : +82-62-610-1761, Fax : +82-62-610-1850

Received 01 April 2020; Revised 07 May 2020; Accepted 11 May 2020.

Copyright (c) The Korean Society of Food Preservation.

This is an Open Access article distributed under the terms of the Creative Commons Attribution Non-Commercial License (http://creativecommons.org/licenses/by-nc/4.0) which permits unrestricted non-commercial use, distribution, and reproduction in any medium, provided the original work is properly cited.
} 
국내 김치 산업체에서 절임 배추는 국산 배추를 주원료로 정선 및 절단, 염수 침지, 세척 냉각과 탈수 공정을 거쳐 비가 열 제조된다. 그러나 대부분의 중소 규모 김치 산업체의 경우, 절임 공정에서 계절별 배추 특성, 염수 온도와 작업장 내 온 도 조건은 고려하지 못하고 있는 실정이다(Jeong 등, 2011; $\mathrm{Kim}$ 등, 2018). 이로 인해 절임 공정은 2절 배추를 $10-15 \%$ 염수로 채워진 절임 탱크에 옮긴 후 격자형 상판으로 눌러 염수에 잠기도록 하고, 하절기에 약 8-10시간, 동절기에 14시 간 이상 각각 소요된다. 특히 김치 제조공정 중 절임은 가장 많은 시간을 차지하기 때문에 소비자 수요 변동에 대응한 김 치 또는 절임 배추 생산량 계획 수립에 장애가 된다(Choi 등, 2015b). 그러므로 김치 산업적 측면에서 배추절임 시간 단축 을 위한 공정 개선 연구가 필요하다.

초고압 가공 기술은 비열 처리 방법으로써 2000년대 이후 식품 산업에 본격적으로 이용되어왔다(Maitland 등, 2011). 초고압 공정은 vessel 내부 물이나 oil을 압력 매체로 $100-800 \mathrm{MPa}$ 압력을 일정 시간 가하여 고형 또는 액상형 식 품의 미생물 사멸, 효소 불활성화와 물성 개선 효과를 나타내 며, 세포막 투과성을 증대시켜 물질 이동을 용이하게 하는 장 점이 있다(O’Neill, 2019). 또한, 플라스틱 파우치나 용기 포 장한 식품에 초고압 처리가 가능하며, 가열 처리와 비교하여 식품의 색, 영양 성분, 향미와 연관된 화학적 반응에는 최소 한의 영향을 미친다(Huang 등, 2019). 국외에서 초고압 전처 리에 따른 감자의 삼투압 건조 효율 증대와 초고압 조건에서 glucose, fructose와 sucrose를 이용한 절단 생강의 삼투압 탈 수 처리 시 상압 조건에 비해 높은 수분 손실률과 용질 흡수 율을 보인 연구 결과가 보고되었다(Dash 등, 2019; Rastogi 등, 2000). 국내에서 초고압 기술을 이용한 농식품 가공연구 와 관련하여 자작나무 수액의 저장성 향상(Choi 등, 2017), 더덕 및 발효더덕 추출물 항산화 활성 증대(Park 등, 2010), 찹쌀과 현미의 가공적성 개선(Cheon 등, 2016)과 막걸리 발 효 조절(Ha 등, 2012), 비지 현탁액의 추출 수율과 영양 성분 증가(Lee, 2015) 등이 보고된 바 있다. 절임 배추 가공 관련 국내 연구는 절임 방법(염수법, 건염법 또는 혼합법)과 소금 종류에 따른 절임 배추의 품질 특성(Choi 등, 2014), 전해수 를 이용한 배추절임과 절임 후 세척(Park 등, 2013), 절임 배 추에 저온살균 처리와 유산균 첨가(Han 등, 2011)가 보고되 었다. 그러나 현재까지 초고압 기술을 적용한 절임 배추의 가 공공정 개선 연구는 수행된 바 없다.

따라서 본 연구는 초고압 조건에서 절임 중 압력 강도와 염수 농도가 배추의 이화학적 품질과 미세 구조 변화에 미치 는 영향을 분석하여 초고압 배추절임 기술에 대한 기초 자료 를 확보하고자 수행하였다.

\section{재료 및 방법}

\section{재료}

본 연구의 재료는 2020년 1월 28일 전남 진도에서 수확한 겨울배추 '동풍' 품종(Brassica rapa L. ssp. pekinensis)을 이 용하였다. 수확된 배추는 high-density polyethylene 박스에 4 포기씩 세워 담은 후 광주 남구 소재 연구실로 운송하였다. 외관 손상이 없는 배추를 시료로 선별 후 비가식 겉잎은 제거 하였다. 초고압 절임을 위한 시료는 배추 시료 형태에 따라 낱장형과 절단형 2그룹으로 나누었다. 낱장형 시료는 포기 배추를 낱장으로 분리 후 낱장 길이가 $25 \pm 3 \mathrm{~cm}$ 인 것을 선별 하였고, 절단형 시료는 낱장의 중륵 두께가 $0.7 \pm 0.1 \mathrm{~cm}$ 인 줄 기 부분을 $4 \times 4 \mathrm{~cm}$ 크기로 절단하여 준비하였다.

\section{절임 염수 제조}

낱장형과 절단형 배추 시료의 절임을 위한 염수는 1 차 증 류수에 정제염(Hanju Co., Ulsan, Korea)을 10, 12와 15\% $(\mathrm{w} / \mathrm{v})$ 농도로 각각 첨가하여 제조하였다. Low-density polyethylene(LDPE) film bag에 낱장형과 절단형 시료 $300 \mathrm{~g}$ 을 각 각 넣은 후 절임 염수는 시료 중량에 $2: 1(\mathrm{v} / \mathrm{w})$ 비율로 첨가하 였다.

\section{초고압 절임}

High-hydrostatic-pressure(HHP) system(R-SCS SW, ChemRe SYStem Inc., Anyang, Korea)은 배추의 초고압 절임 처리에 이용하였다. LDPE film bag 안 염수 침지된 낱장형과 절단 형 배추 시료는 HHP system 내부에 위치한 $6 \mathrm{~L}$ 용량의 원통 형 stainless steel vessel에 넣고 50, 100과 $200 \mathrm{MPa}$ 로 5 분 동안 각각 처리하였다. 가압 중 vessel 안에 채워진 pressuretransmitting oil(Maxifluid, Maximator GmbH, Nordhausen, Germany)의 최대 상승온도는 약 $30^{\circ} \mathrm{C}$ 이었으며, 감압(depressurization)은 1 분 이내로 이루어졌다. 초고압 절임 완료 후 film bag 내부 염수는 즉시 제거하였으며, 배추 시료는 소형 탈수기(Zyliss Smart Touch Salad Spinner, Zyliss Corp., Farnborough, UK)를 이용하여 3분간 탈수를 실시하였다. 초 고압 절임 동안 대기압과 실온 조건에서 절임한 배추 시료는 대조구로 하였다.

\section{절임 배추의 염도와 전기전도도 분석}

절임 배추의 염도와 전기전도도 분석을 위해 시료는 hand blender(HR1390, Philips, Guangzhou, China)를 이용하여 3 분간 균질화시켰다. 염도는 Mohr법에 따라 시료액 $10 \mathrm{~mL}$ 에 $2 \% \mathrm{~K}_{2} \mathrm{Cr}_{2} \mathrm{O}_{4}$ 용액 $1 \mathrm{~mL}$ 를 첨가한 다음 $0.02 \mathrm{~N} \mathrm{AgNO}_{3}$ 용액 으로 적갈색의 난용성 침전이 형성될 때까지 적정한 후 0.02 
$\mathrm{N} \mathrm{AgNO}_{3}$ 용액의 소비량을 통해 \%로 나타내었다. 전기전도 도는 multiparameter benchtop meter(Orion VERSA STAR 90, Thermo Fisher Scientific Inc., Chelmsford, MA, USA)에 electrical conductivity(EC) probe(Orion 013005MD Conductivity Cell, Thermo Fisher Scientific Inc.)를 장착 및 EC 표 준용액으로 보정 후 실온에서 측정하였다.

\section{절임 배추의 수분함량, water loss와 solid gain 측정}

수분함량은 균질한 시료 $2 \mathrm{~g}$ 을 aluminum weighting dish 에 취한 후 적외선 수분측정기(MB45, Ohaus Co., Pine Brook, NJ, USA)를 이용하여 측정하였다. Water loss는 절임 전과 후의 배추 시료의 중량 및 수분함량 측정을 통해 아래의 수식을 이용하여 계산하였다(Dash 등, 2019).

Water loss $(\mathrm{g} / \mathrm{g})=\left(\mathrm{W}_{\mathrm{i}} \times \mathrm{M}_{\mathrm{i}}\right)-\left(\mathrm{W}_{\mathrm{f}} \times \mathrm{M}_{\mathrm{f}}\right) / \mathrm{W}_{\mathrm{i}}\left(1-\mathrm{M}_{\mathrm{i}}\right)$

$\mathrm{W}_{\mathrm{i}}$ : 초기 시료의 중량 $(\mathrm{g})$

$\mathrm{W}_{\mathrm{f}}$ : 절임 후 시료의 중량 $(\mathrm{g})$

$\mathrm{M}_{\mathrm{i}}$ : 초기 시료의 수분함량 $(\mathrm{g} / \mathrm{g})$

$\mathrm{M}_{\mathrm{f}}$ : 절임 후 시료의 수분함량 $(\mathrm{g} / \mathrm{g})$

Solid gain은 절임 전과 후의 배추 시료의 무게 및 고형물 함량 측정 후 아래의 수식을 이용하여 산출하였다(Dash 등, 2019).

Solid gain $(\mathrm{g} / \mathrm{g})=\mathrm{W}_{\mathrm{f}}\left(1-\mathrm{S}_{\mathrm{f}}\right)-\mathrm{W}_{\mathrm{i}}\left(1-\mathrm{S}_{\mathrm{i}}\right) / \mathrm{W}_{\mathrm{i}}\left(1-\mathrm{S}_{\mathrm{i}}\right)$

$\mathrm{W}_{\mathrm{i}}$ : 초기 시료의 중량 $(\mathrm{g})$

$\mathrm{W}_{\mathrm{f}}$ : 절임 후 시료의 중량 $(\mathrm{g})$

$\mathrm{S}_{\mathrm{i}}$ : 초기 시료의 고형물 함량 $(\mathrm{g} / \mathrm{g})$

$\mathrm{S}_{\mathrm{f}}$ 절임 후 시료의 고형물 함량 $(\mathrm{g} / \mathrm{g})$

\section{절임 배추의 백색도와 경도 분석}

초고압 절임에 따른 배추의 백색도와 경도 변화를 분석하 기 위해 낱장형 시료는 줄기 부분을 $4 \times 4 \mathrm{~cm}$ 로 절단하여 절단 형 시료와 동일한 크기로 준비하였다. Whiteness index(WI) 값은 색차계(Chroma meter CR-400, Konica Minolta Inc., Tokyo, Japan)를 이용하여 측정된 시료의 CIE L*, a*와 b* 값을 아래의 수식에 대입하여 산출하였다.

$$
\mathrm{WI}=100-\left[\left(\mathrm{L}^{*}-100\right)^{2}+\left(\mathrm{a}^{*}\right)^{2}+\left(\mathrm{b}^{*}\right)^{2}\right]^{1 / 2}
$$

기계적 경도는 texture analyzer(TA-XT Plus, Stable Micro Systems Ltd., Surrey, UK)에 장착된 직경 $2 \mathrm{~mm}$ 의 원통형 probe가 $10 \mathrm{~mm} / \mathrm{s}$ 의 속도로 시료를 관통할 때 얻어지는 최대 값을 측정하였다. 시료 측정 횟수는 각 처리구당 10 회 이상 반복하였으며, 평균값은 $\mathrm{kg}_{f}$ 로 나타내었다.

\section{절임 배추의 조직학적 관찰}

초고압 절임 후 배추 세포조직의 형태학적 변화를 관찰하 기 위해 절단형 절임 배추 시료는 $1 \times 1 \mathrm{~cm}$ 크기로 절단하였 다. 절단한 시료는 $2 \%$ glutaraldehyde( $\mathrm{pH}$ 7.2) 용액으로 4시 간 고정 후 $50,70,90$ 과 $95 \%$ ethanol에 순차적으로 침지시켜 탈수하였다. 탈수 완료한 시료는 $100 \%$ ethanol과 isoamyl acetate 용액으로 20 분씩 각각 처리하였으며, 임계점 건조가 끝난 시료는 백금 코팅 후 주사전자현미경(S-2400, Hitachi Ltd., Tokyo, Japan)을 사용하여 $2.0 \mathrm{kV}$ 에서 5,000 배 배율로 관찰하였다.

절임 중 배추 조직에 염수가 침투한 양상을 시료 발색 정 도로 확인하기 위해 낱장형과 절단형 배추 시료는 neutral red(Sigma-Aldrich Co., Oakville, Canada)가 $25 \mathrm{mg} / \mathrm{L}$ 농도 로 첨가된 염수에 침지 후 50,100 과 $200 \mathrm{MPa}$ 압력 조건에서 5 분간 각각 절임을 실시하였다. 절임 후 배추의 색상 변화는 시료의 증류수 세척, 탈수와 표면 물기 제거 과정을 거친 후 디지털카메라(DSC-RX100, Sony Corp., Tokyo, Japan)로 관 찰하였다.

\section{통계처리}

모든 실험결과는 3회 이상 반복 수행하여 평균값 \pm 표준편 차로 나타냈으며, 통계 분석은 SPSS(Statistical Package for the Social Science, Version 19, SPSS Inc., Chicago, IL, USA) program을 이용하여 검증하였다. 처리구간 사후검증 은 one-way ANOVA를 행한 후 $\mathrm{p}<0.05$ 수준에서 Duncan's multiple range test를 실시하였다. 절임 중 배추의 이화학적 품질 변화에 배추 시료 형태, 염수 $\mathrm{NaCl}$ 농도와 초고압 강도 의 상호작용 효과 분석은 three-way ANOVA를 이용하였다.

\section{결과 및 고찰}

\section{절임 배추의 염도와 전기전도도}

초고압 조건에서 염수 절임 후 낱장형과 절단형 배추의 염 도와 전기전도도 변화는 Table 1에 나타내었다. $10-15 \%$ 염 수에서 절임한 낱장형 배추 시료의 경우, 대조구의 염도는 $0.25-0.28 \%$ 인 반면 HHP- $50, \mathrm{HHP}-100$ 과 HHP-200 처리구의 염도는 0.84-1.26\%로 압력 강도와 염수 농도가 증가함에 따 라 유의적으로 증가하였다 $(\mathrm{p}<0.05)$. 절단형 절임 배추의 염 도 결과는 낱장형 시료와 유사한 경향을 나타냈는데, 동일한 염수 $\mathrm{NaCl}$ 농도 조건에서 HHP-50, HHP-100과 HHP-200 처 
Table 1. Changes in the salinity and electrical conductivity of kimchi cabbage after salting under high-hydrostatic-pressure conditions

\begin{tabular}{|c|c|c|c|c|c|c|c|}
\hline \multirow{2}{*}{ Parameter } & \multirow{2}{*}{$\begin{array}{c}\text { Kimchi } \\
\text { cabbage type }\end{array}$} & \multirow{2}{*}{ Treatment } & \multicolumn{3}{|c|}{ Brine concentration $(\%)$} & \multirow{2}{*}{\multicolumn{2}{|c|}{ Levels of significance }} \\
\hline & & & 10 & 12 & 15 & & \\
\hline \multirow{8}{*}{$\begin{array}{c}\text { Salinity } \\
(\%)\end{array}$} & \multirow{4}{*}{ Piece } & Control & $0.25 \pm 0.02^{2) \mathrm{Ea} 3)}$ & $0.28 \pm 0.03^{\mathrm{Fa}}$ & $0.28 \pm 0.02^{\mathrm{Ea}}$ & $\mathrm{CT}^{4)}$ & $* * * 5)$ \\
\hline & & HHP-50 $0^{1)}$ & $0.84 \pm 0.02^{\mathrm{Cb}}$ & $0.87 \pm 0.02^{\mathrm{Db}}$ & $0.92 \pm 0.02^{\mathrm{Da}}$ & $\mathrm{PC}$ & $* * *$ \\
\hline & & HHP-100 & $0.85 \pm 0.03^{\mathrm{Cc}}$ & $1.10 \pm 0.05^{\mathrm{Cb}}$ & $1.23 \pm 0.02^{\mathrm{Ca}}$ & $\mathrm{BC}$ & $* * *$ \\
\hline & & HHP-200 & $0.89 \pm 0.04^{\mathrm{Cc}}$ & $1.12 \pm 0.02^{\mathrm{Cb}}$ & $1.26 \pm 0.02^{\mathrm{Ca}}$ & \multirow{2}{*}{$\mathrm{CT} \times \mathrm{PC}$} & \multirow{2}{*}{$* * *$} \\
\hline & \multirow{4}{*}{ Shred } & Control & $0.67 \pm 0.05^{\mathrm{Dc}}$ & $0.80 \pm 0.02^{\mathrm{Eb}}$ & $0.89 \pm 0.05^{\mathrm{Da}}$ & & \\
\hline & & HHP-50 & $1.51 \pm 0.02^{\mathrm{Bc}}$ & $1.77 \pm 0.02^{\mathrm{Bb}}$ & $2.18 \pm 0.02^{\mathrm{Ba}}$ & $\mathrm{CT} \times \mathrm{BC}$ & $* * *$ \\
\hline & & HHP-100 & $1.68 \pm 0.03^{\mathrm{Ac}}$ & $1.78 \pm 0.04^{\mathrm{Bb}}$ & $2.22 \pm 0.06^{\mathrm{Ba}}$ & $\mathrm{PC} \times \mathrm{BC}$ & $* * *$ \\
\hline & & HHP-200 & $1.69 \pm 0.02^{\mathrm{Ac}}$ & $2.07 \pm 0.04^{\mathrm{Ab}}$ & $2.52 \pm 0.01^{\mathrm{Aa}}$ & $\mathrm{CT} \times \mathrm{PC} \times \mathrm{BC}$ & $* * *$ \\
\hline \multirow{8}{*}{$\begin{array}{c}\text { Electrical } \\
\text { conductivity } \\
(\mathrm{S} / \mathrm{m})\end{array}$} & \multirow{4}{*}{ Piece } & Control & $5.93 \pm 0.19^{\mathrm{Gb}}$ & $6.98 \pm 0.28^{\mathrm{Ga}}$ & $6.92 \pm 0.55^{\mathrm{Ga}}$ & $\mathrm{CT}$ & $* * *$ \\
\hline & & HHP-50 & $7.86 \pm 0.27^{\mathrm{Fb}}$ & $9.56 \pm 0.41^{\mathrm{Fa}}$ & $9.84 \pm 0.57^{\mathrm{Fa}}$ & $\mathrm{PC}$ & $* * *$ \\
\hline & & HHP-100 & $8.93 \pm 0.46^{\mathrm{Eb}}$ & $10.80 \pm 0.60^{\mathrm{EFa}}$ & $11.20 \pm 0.39^{\mathrm{EFa}}$ & \multirow{2}{*}{$\mathrm{BC}$} & \multirow{2}{*}{$* * *$} \\
\hline & & HНP-200 & $10.35 \pm 0.77^{\mathrm{Db}}$ & $11.94 \pm 1.01^{\text {Eab }}$ & $12.34 \pm 0.60^{\mathrm{Ea}}$ & & \\
\hline & \multirow{4}{*}{ Shred } & Control & $12.86 \pm 0.52^{\mathrm{Cc}}$ & $14.63 \pm 0.46^{\mathrm{Db}}$ & $16.12 \pm 0.76^{\mathrm{Da}}$ & $\mathrm{CT} \times \mathrm{PC}$ & $* * *$ \\
\hline & & HHP-50 & $22.89 \pm 0.46^{\mathrm{Bb}}$ & $25.16 \pm 1.11^{\mathrm{Cb}}$ & $29.60 \pm 1.75^{\mathrm{Ca}}$ & $\mathrm{CT} \times \mathrm{BC}$ & $* * *$ \\
\hline & & HHP-100 & $25.51 \pm 0.04^{\mathrm{Ab}}$ & $27.29 \pm 1.59^{\mathrm{Bb}}$ & $31.46 \pm 1.17^{\mathrm{Ba}}$ & $\mathrm{PC} \times \mathrm{BC}$ & $* * *$ \\
\hline & & HHP-200 & $26.28 \pm 0.72^{\mathrm{Ac}}$ & $29.19 \pm 0.83^{\mathrm{Ab}}$ & $36.25 \pm 1.12^{\mathrm{Aa}}$ & $\mathrm{CT} \times \mathrm{PC} \times \mathrm{BC}$ & $* *$ \\
\hline
\end{tabular}

${ }^{1)} \mathrm{HHP}-50,50 \mathrm{MPa}$ high-hydrostatic-pressure treatment for $5 \mathrm{~min}$; HHP-100, $100 \mathrm{MPa}$ high-hydrostatic-pressure treatment for 5 min; HHP-200, $200 \mathrm{MPa}$ high-hydrostatic-pressure treatment for $5 \mathrm{~min}$.

${ }^{2)}$ Each value is mean $\pm \mathrm{SD} \quad(\mathrm{n}=3)$.

${ }^{3}$ Mean values in the same column $\left({ }^{\mathrm{A}-\mathrm{G}}\right)$ or row $\left({ }^{\mathrm{a}-\mathrm{c}}\right)$ followed by different letters are significantly different according to Duncan's multiple range test $(\mathrm{p}<0.05)$.

${ }^{4)} \mathrm{CT}$, cabbage type; $\mathrm{PC}$, pressure condition; $\mathrm{BC}$, brine concentration.

${ }^{5)}$ Level of significance: ${ }^{*} \mathrm{p}<0.01 ;{ }^{* * *} \mathrm{p}<0.001$.

리구의 염도가 대조구에 비해 높은 값을 보였다. 특히 $15 \%$ 염수에서 절단형 HHP-200 처리구는 $2.52 \%$ 로 절단형 대조구 $(0.89 \%)$ 대비 약 2.8 배 높은 염도 값을 나타냈다. 한편, 50 , 100 과 $200 \mathrm{MPa}$ 조건에서 10,12 와 $15 \%$ 염수로 각각 절임한 절단형 배추 시료의 염도는 동일 압력과 염수 조건으로 절임 한 낱장형 배추 시료와 비교하여 유의적으로 높은 값을 보였 다(p<0.05)(Table 1). 이러한 결과는 초고압 절임 시 배추 형 태에 따라 염도 조절에 필요한 압력 조건과 염수 $\mathrm{NaCl}$ 농도 설정이 차이가 있음을 입증하였다. Nunez-Mancilla 등(2013) 은 $40{ }^{\circ} \mathrm{Brix}$ 용액에 침지된 슬라이스 딸기를 0.1 과 $500 \mathrm{MPa}$ 조건에서 10 분간 처리 후 시료의 당도가 7.3 과 $12.3{ }^{\circ} \mathrm{Brix}$ 로 각각 나타나 초고압 적용에 따른 당절임 소요시간 감소를 보 고하였는데, 본 연구 결과와 유사하였다. 대기압 환경에서 10 과 $15 \%$ 염수를 이용한 배추절임 공정은 삼투작용에 의한 배
추 조직 내 $\mathrm{NaCl}$ 확산과 수분 유출로 절임 배추의 염도가 $2.8 \%$ 까지 도달하는데 약 6-10시간이 소요되며, 절임 시간이 길어질수록 배추에 존재하는 수용성 물질이 과다 용출되기 때문에 장시간 절임은 절임 배추에 부정적 영항을 미칠 수 있다(Shim 등, 2003). 한편, 상압 조건에서 phytic acid 첨가 한 $20 \%$ 고농도 염수를 이용한 절임 방법이 절단 배추의 절임 소요시간을 10-18시간에서 6시간으로 단축시켰다는 Kim 등 (2015)의 보고와 비교하여 본 연구의 초고압 절임은 $10-15 \%$ 염수를 이용하여 10 여 분 내로 절단 배추의 염도가 $1.5-2.5 \%$ 에 도달할 수 있는 특징이 있다.

$10 \%$ 염수에서 절임 후 낱장형 대조구의 전기전도도는 $5.93 \mathrm{~S} / \mathrm{m}$ 로 나타난 반면, 낱장형 HHP-100과 HHP-200 처리 구의 전기전도도는 8.93 과 $10.35 \mathrm{~S} / \mathrm{m}$ 에 각각 도달하여 초고 압 강도에 따른 뚜렷한 전기전도도 차이가 확인되었다(Table 
1). 12 와 $15 \%$ 염수에서 절임한 낱장형 $\mathrm{HHP}-50, \mathrm{HHP}-100$ 과 HHP-200 처리구의 전기전도도는 $10 \%$ 염수 조건과 유사하 게 초고압 강도가 증가함에 따라 증가하는 경향을 나타냈다. 절단형 HHP-50, HHP-100과 HHP-200 처리구의 전기전도도 도 절임 염수 $\mathrm{NaCl}$ 농도가 증가함에 따라 유의적으로 $(\mathrm{p}<0.05)$ 증가하였으며, 특히 $15 \%$ 염수에 절임한 절단형 HHP-200 처리구의 전기전도도는 $36.25 \mathrm{~S} / \mathrm{m}$ 으로 처리구 중 가장 높은 값을 나타냈다. 초고압 절임한 배추 시료의 염도와 전기전도도 변화는 배추 형태, 초고압 강도와 절임 염수 $\mathrm{NaCl}$ 농도 간에 삼원 상호작용 효과가 유의한 것으로( $\mathrm{p}<0.001$ 또는 $\mathrm{p}<0.01)$ 나타났다. Taiwo 등(2003)은 $200 \mathrm{MPa}$ 에서 5분간 전 처리한 슬라이스 딸기 시료를 대기압 환경에서 $50{ }^{\circ} \mathrm{Brix}$ salt-sucrose 용액에 4시간 동안 침지한 결과, 딸기 시료의 전 기전도도가 초고압 전처리하지 않은 대조구 대비 약 3 배 증 가했다고 보고하였다. Duguay 등(2017)은 $0.15,1$ 과 $1.85 \%$ 염수 침지한 절단 양배추 시료의 전기전도도는 ohmic heating 후 $0.01,0.37$ 과 $0.80 \mathrm{~S} / \mathrm{m}$ 으로 각각 증가하여 염수의 $\mathrm{NaCl}$ 농도가 ohmic heating 처리된 양배추 전기전도도 변화에 영 향을 미쳤다고 보고한 바 있다. 또한, Verma 등(2014)은 200 $\mathrm{MPa}$ 초고압 전처리가 슬라이스 바나나의 세포막 투과성 상승 에 의한 mass transfer coefficient를 증가시켰으며, 당절임에 소요되는 시간과 에너지를 감소시킬 수 있다고 보고하였다.

\section{절임 배추의 수분함량, water loss와 solid gain}

$10 \%$ 염수로 절임한 낱장형 대조구의 수분함량은 $91.50 \%$ 로 절임 전 낱장형 배추 시료(91.65\%)와 차이를 보이지 않았 다(Table 2). 반면, 100 과 $200 \mathrm{MPa}$ 하에서 $10 \%$ 염수로 절임 한 낱장형 배추 시료의 수분함량은 89.59 와 $89.53 \%$ 로 각각 나타났다. 절단형 배추 시료의 수분함량도 압력 강도와 염수 $\mathrm{NaCl}$ 농도가 증가함에 따라 유의적으로 감소하였다 $(\mathrm{p}<0.05)$. 특히 $15 \%$ 염수로 절임한 절단형 HHP-200 처리구의 수분함 량은 $91.60 \%$ 로 절단형 대조구(93.27\%)에 비해 약 $1.7 \%$ 낮 게 나타났다. Lee 등(2011)은 $15^{\circ} \mathrm{C}$ 에서 6 시간 동안 1,6 과 $10 \%$ 염수 절임 후 절단 배추 시료의 수분함량이 95.04 , 92.42 와 $90.00 \%$ 로 각각 측정되어 염수 $\mathrm{NaCl}$ 농도와 절임 배 추 수분함량의 높은 상관성을 보고하였으며, 이는 본 연구 결 과와 일치하였다.

삼투성 탈수에 의한 water loss와 solid gain은 절임 가공공 정의 탈수율과 물질전달 효율을 평가하기 위한 중요한 요소 이다(Wang 등, 2015). 염수 $\mathrm{NaCl}$ 농도와 압력 강도를 달리하 여 절임한 낱장형과 절단형 배추 시료의 water loss, solid gain과 수분함량 변화는 Table 2에 나타내었다. 초고압 절임 시 압력 강도가 높을수록 낱장형 배추의 water loss는 유의적 으로 증가하였다 $(\mathrm{p}<0.05) .10$ 과 $15 \%$ 염수에서 각각 절임한
낱장형 HHP-100 처리구의 water loss는 0.23 과 $0.49 \mathrm{~g} / \mathrm{g}$ 으로 염수 $\mathrm{NaCl}$ 농도에 따른 유의적인 차이를 보였다 $(\mathrm{p}<0.05)$. 또 한 $10 \%$ 염수로 절임한 절단형 HHP-200 처리구의 water loss 는 절단형 대조구 $(0.20 \mathrm{~g} / \mathrm{g})$ 와 비교하여 약 10.6배 증가한 $2.11 \mathrm{~g} / \mathrm{g}$ 으로 나타났다(Table 2).

절임 배추의 solid gain은 water loss 결과와 유사한 경향을 보였는데, 12 와 $15 \%$ 염수로 절임한 낱장형 HHP-200 처리구 의 solid gain은 $10 \%$ 염수 조건 대비 0.07 과 $0.12 \mathrm{~g} / \mathrm{g}$ 각각 증가하여 염수 $\mathrm{NaCl}$ 농도에 따라 유의적 차이를 보였다 $(\mathrm{p}<0.05)($ Table 2). 또한, $10 \%$ 염수 조건에서 절단형 HHP-50 과 HHP-200 처리구의 solid gain은 절단형 대조구와 비교하 여 2.5와 5.5배 각각 증가하여 압력 조건에 따른 영향을 나타 냈다. Wang 등(2015)은 30-60 ${ }^{\circ}$ Brix sucrose 용액에 절단 사 과를 120 분간 vacuum impregnation 처리한 결과, sucrose 용 액의 ${ }^{\circ}$ Brix가 높을수록 절단 사과의 solid gain과 water loss 가 유의적으로 증가한 결과를 보고하였다. 또한, Verma 등 (2014)은 슬라이스 바나나를 $40^{\circ} \mathrm{C}$ 의 $60^{\circ}$ Brix sucrose 용액에 4시간 동안 침지 후 water loss와 solid gain을 관찰한 결과, $200 \mathrm{MPa}$ 초고압 전처리한 시료의 water loss와 solid gain이 일반 시료에 비해 1.2 와 1.4 배 각각 증가한 결과를 보고하였 다. Three-way ANOVA 결과, 절임 배추의 수분함량은 배추 형태, 염수 $\mathrm{NaCl}$ 농도 또는 초고압 강도 요인에 대한 주 효과 $(\mathrm{p}<0.001)$ 만 나타난 반면, 절임 배추의 water loss와 solid gain은 세 요인 간 상호작용 효과의 유의성이 확인되었다.

\section{절임 배추의 백색도와 경도}

절임 배추의 색과 경도는 소비자가 품질을 판단할 때 중요 하게 고려하는 물리적 품질 인자로 알려져 있다(Choi 등, 2015a). 배추 시료 형태, 염수 $\mathrm{NaCl}$ 농도와 초고압 강도 조건 에 따른 절임 배추 줄기 부위의 백색도와 경도 변화는 Table 3 에 나타내었다. 10,12 와 $15 \%$ 염수에 절임한 낱장형 대조구 의 백색도 값은 $70.25,73.06$ 과 72.68 로 각각 나타나 염수 $\mathrm{NaCl}$ 농도에 따른 유의적 차이를 보이지 않았다 $(\mathrm{p}>0.05)$. 또 한 $10 \%$ 염수로 초고압 절임한 낱장형 HHP-50, HHP-100과 HHP-200 처리구의 백색도 값은 69.76-70.44로 처리구간에 유의적 차이가 없었다( $\mathrm{p}>0.05)$. 그러나 $200 \mathrm{MPa}$ 압력 조건 에서 $15 \%$ 염수로 절임한 낱장형 HHP-200 처리구의 백색도 값은 63.27 까지 감소하였다. $15 \%$ 염수로 절임한 절단형 대 조구의 백색도 값은 64.15 로 나타나 10 과 $12 \%$ 염수와 비교 하여 유의적으로 감소하였다( $\mathrm{p}<0.05)$. 이러한 염수 $\mathrm{NaCl}$ 농 도별 절임 배추의 백색도 차이는 세포조직 내 삼투압에 의한 $\mathrm{NaCl}$ 침투 속도, 수분 손실량 및 구조적 변형과 관련 있는 것으로 추론된다. 또한, 10,12 와 $15 \%$ 염수로 절임한 절단형 $\mathrm{HHP}-50, \mathrm{HHP}-100$ 과 HHP-200 처리구의 백색도 값은 50 이하 
Table 2. Changes in moisture content, water loss, and solid gain of kimchi cabbage after salting under high-hydrostatic-pressure conditions

\begin{tabular}{|c|c|c|c|c|c|c|c|}
\hline \multirow{2}{*}{ Parameter } & \multirow{2}{*}{$\begin{array}{c}\text { Kimchi } \\
\text { cabbage type }\end{array}$} & \multirow{2}{*}{ Treatment } & \multicolumn{3}{|c|}{ Brine concentration $(\%)$} & \multirow{2}{*}{\multicolumn{2}{|c|}{ Levels of significance }} \\
\hline & & & 10 & 12 & 15 & & \\
\hline \multirow{8}{*}{$\begin{array}{l}\text { Moisture } \\
\text { content } \\
(\%)\end{array}$} & \multirow{4}{*}{ Piece } & Control & $91.50 \pm 0.28^{2) \mathrm{Da} 3)}$ & $90.81 \pm 0.25^{\mathrm{Db}}$ & $90.40 \pm 0.43^{\mathrm{Cb}}$ & $\mathrm{CT}^{4)}$ & $* * * 5)$ \\
\hline & & HHP-50 ${ }^{1)}$ & $90.29 \pm 0.29^{\mathrm{Ea}}$ & $89.58 \pm 0.20^{\mathrm{Ea}}$ & $89.63 \pm 0.48^{\mathrm{Da}}$ & $\mathrm{PC}$ & $* * *$ \\
\hline & & HHP-100 & $89.59 \pm 0.35^{\mathrm{Fa}}$ & $88.96 \pm 0.46^{\mathrm{Fab}}$ & $88.60 \pm 0.38^{\mathrm{Eb}}$ & $\mathrm{BC}$ & $* * *$ \\
\hline & & HHP-200 & $89.53 \pm 0.24^{\mathrm{Fa}}$ & $88.84 \pm 0.64^{\mathrm{Fab}}$ & $88.52 \pm 0.25^{\mathrm{Eb}}$ & $\mathrm{CT} \times \mathrm{PC}$ & NS \\
\hline & \multirow{4}{*}{ Shred } & Control & $94.31 \pm 0.11^{\mathrm{Aa}}$ & $93.57 \pm 0.32^{\mathrm{Ab}}$ & $93.27 \pm 0.23^{\mathrm{Ab}}$ & \multirow{2}{*}{$\mathrm{CT} \times \mathrm{BC}$} & NS \\
\hline & & HHP-50 & $93.43 \pm 0.29^{\mathrm{Ba}}$ & $92.37 \pm 0.14^{\mathrm{Bb}}$ & $91.96 \pm 0.03^{\mathrm{Bc}}$ & & \multirow{2}{*}{ NS } \\
\hline & & HHP-100 & $92.70 \pm 0.12^{\mathrm{Ca}}$ & $92.26 \pm 0.17^{\mathrm{BCa}}$ & $91.72 \pm 0.39^{\mathrm{Bb}}$ & $\mathrm{PC} \times \mathrm{BC}$ & \\
\hline & & HHP-200 & $92.53 \pm 0.12^{\mathrm{Ca}}$ & $91.69 \pm 0.13^{\mathrm{Cb}}$ & $91.60 \pm 0.34^{\mathrm{Bb}}$ & $\mathrm{CT} \times \mathrm{PC} \times \mathrm{BC}$ & NS \\
\hline \multirow{8}{*}{$\begin{array}{l}\text { Water loss } \\
\quad(\mathrm{g} / \mathrm{g})\end{array}$} & \multirow{4}{*}{ Piece } & Control & $0.10 \pm 0.03^{\mathrm{Fb}}$ & $0.20 \pm 0.03^{\mathrm{Ea}}$ & $0.18 \pm 0.05^{\mathrm{Ha}}$ & $\mathrm{CT}$ & $* * *$ \\
\hline & & HHP-50 & $0.14 \pm 0.03^{\mathrm{EFb}}$ & $0.28 \pm 0.02^{\mathrm{Da}}$ & $0.32 \pm 0.06^{\mathrm{Ga}}$ & PC & $* * *$ \\
\hline & & HHP-100 & $0.23 \pm 0.04^{\mathrm{Db}}$ & $0.31 \pm 0.06^{\mathrm{Db}}$ & $0.49 \pm 0.04^{\mathrm{Fa}}$ & \multirow{2}{*}{$\mathrm{BC}$} & \multirow{2}{*}{$* * *$} \\
\hline & & HHP-200 & $0.38 \pm 0.03^{\mathrm{Cb}}$ & $0.58 \pm 0.07^{\mathrm{Ca}}$ & $0.60 \pm 0.03^{\mathrm{Ea}}$ & & \\
\hline & \multirow{4}{*}{ Shred } & Control & $0.20 \pm 0.02^{\mathrm{DEc}}$ & $0.62 \pm 0.06^{\mathrm{Cb}}$ & $0.88 \pm 0.04^{\mathrm{Da}}$ & $\mathrm{CT} \times \mathrm{PC}$ & $* * *$ \\
\hline & & HHP-50 & $1.70 \pm 0.05^{\mathrm{Bb}}$ & $1.73 \pm 0.02^{\mathrm{Bb}}$ & $1.95 \pm 0.01^{\mathrm{Ca}}$ & $\mathrm{CT} \times \mathrm{BC}$ & $* * *$ \\
\hline & & HHP-100 & $1.74 \pm 0.02^{\mathrm{Bb}}$ & $1.69 \pm 0.03^{\mathrm{Bb}}$ & $2.09 \pm 0.06^{\mathrm{Ba}}$ & $\mathrm{PC} \times \mathrm{BC}$ & $* * *$ \\
\hline & & HHP-200 & $2.11 \pm 0.06^{\mathrm{Ab}}$ & $2.15 \pm 0.04^{\mathrm{Ab}}$ & $2.29 \pm 0.06^{\mathrm{Aa}}$ & $\mathrm{CT} \times \mathrm{PC} \times \mathrm{BC}$ & $* * *$ \\
\hline \multirow{8}{*}{$\begin{array}{l}\text { Solid gain } \\
\text { (g/g) }\end{array}$} & \multirow{4}{*}{ Piece } & Control & $0.01 \pm 0.01^{\mathrm{Cb}}$ & $0.19 \pm 0.03^{\mathrm{DEa}}$ & $0.18 \pm 0.05^{\mathrm{Ba}}$ & $\mathrm{CT}$ & $* *$ \\
\hline & & HHP-50 & $0.14 \pm 0.03^{\mathrm{Ba}}$ & $0.22 \pm 0.02^{\mathrm{CDa}}$ & $0.21 \pm 0.06^{\mathrm{Ba}}$ & $\mathrm{PC}$ & $* * *$ \\
\hline & & HHP-100 & $0.23 \pm 0.04^{\mathrm{Aa}}$ & $0.31 \pm 0.06^{\mathrm{Ba}}$ & $0.32 \pm 0.04^{\mathrm{Aa}}$ & \multirow{2}{*}{$\mathrm{BC}$} & \multirow{2}{*}{$* * *$} \\
\hline & & HHP-200 & $0.21 \pm 0.03^{\mathrm{Ab}}$ & $0.28 \pm 0.07^{\mathrm{BCab}}$ & $0.33 \pm 0.03^{\mathrm{Aa}}$ & & \\
\hline & & Control & $0.04 \pm 0.02^{\mathrm{Cb}}$ & $0.13 \pm 0.06^{\mathrm{Ea}}$ & $0.19 \pm 0.04^{\mathrm{Ba}}$ & $C 1 \times 1<$ & No \\
\hline & & HHP-50 & $0.10 \pm 0.05^{\mathrm{Bb}}$ & $0.29 \pm 0.02^{\mathrm{BCa}}$ & $0.35 \pm 0.01^{\mathrm{Aa}}$ & $\mathrm{CT} \times \mathrm{BC}$ & * \\
\hline & snrea & HHP-100 & $0.23 \pm 0.02^{\mathrm{Ab}}$ & $0.32 \pm 0.03^{\mathrm{ABa}}$ & $0.38 \pm 0.06^{\mathrm{Aa}}$ & $\mathrm{PC} \times \mathrm{BC}$ & NS \\
\hline & & HHP-200 & $0.22 \pm 0.02^{\mathrm{Ab}}$ & $0.39 \pm 0.02^{\mathrm{Aa}}$ & $0.38 \pm 0.06^{\mathrm{Aa}}$ & $\mathrm{CT} \times \mathrm{PC} \times \mathrm{BC}$ & $*$ \\
\hline
\end{tabular}

${ }^{1)} \mathrm{HHP}-50,50 \mathrm{MPa}$ high-hydrostatic-pressure treatment for $5 \mathrm{~min}$; HHP-100, $100 \mathrm{MPa}$ high-hydrostatic-pressure treatment for 5 min; HHP-200, 200 $\mathrm{MPa}$ high-hydrostatic-pressure treatment for $5 \mathrm{~min}$.

${ }^{2)}$ Each value is mean $\pm \mathrm{SD}(\mathrm{n}=3)$.

${ }^{3}$ Mean values in the same column $\left({ }^{\mathrm{A}-\mathrm{H}}\right)$ or row $\left({ }^{\mathrm{a}-\mathrm{c}}\right)$ followed by different letters are significantly different according to Duncan's multiple range test $(\mathrm{p}<0.05)$.

${ }^{4)} \mathrm{CT}$, cabbage type; $\mathrm{PC}$, pressure condition; $\mathrm{BC}$, brine concentration.

${ }^{5}$ Level of significance: NS, not significant; ${ }^{*} \mathrm{p}<0.05 ;{ }^{* *} \mathrm{p}<0.01 ;{ }^{* * * *} \mathrm{p}<0.001$.

로 감소하였다. Rux 등(2019)은 20 또는 $30^{\circ} \mathrm{C}$ 에서 $100 \mathrm{MPa}$ 초고압 5 분 처리 후 무의 백색도 값이 초고압 처리 전과 비교 하여 뚜렷한 차이가 없었으나, 20-40 $\mathrm{C}$ 에서 150-200 MPa 초 고압 10 분 처리는 무의 백색도를 유의적으로 증가시켰다는 결 과를 보고하였다. 따라서 본 연구와 선행 연구 결과는 초고압
처리에 의한 농산물 색도 변화가 시료 종류와 처리 압력 강도 또는 처리 온도와 시간에 따라 차이 있음을 시사한다.

신선 배추 시료의 경도는 $0.48 \mathrm{~kg}_{\mathrm{f}}$ 이었으며(data not shown) 10,12 와 $15 \%$ 염수로 초고압 절임한 낱장형 HHP-50, $\mathrm{HHP}-100$ 과 HHP-200 처리구의 경도는 $0.53-0.56 \mathrm{~kg}_{\mathrm{f}}$ 로 나타 
Table 3. Changes in whiteness index and instrumental firmness of kimchi cabbages after salting under high-hydrostatic-pressure conditions

\begin{tabular}{|c|c|c|c|c|c|c|c|}
\hline \multirow{2}{*}{ Parameter } & \multirow{2}{*}{$\begin{array}{c}\text { Kimchi } \\
\text { cabbage type }\end{array}$} & \multirow{2}{*}{ Treatment } & \multicolumn{3}{|c|}{ Brine concentration $(\%)$} & \multirow{2}{*}{\multicolumn{2}{|c|}{ Levels of significance }} \\
\hline & & & 10 & 12 & 15 & & \\
\hline \multirow{8}{*}{$\begin{array}{l}\text { Whiteness } \\
\text { index }\end{array}$} & \multirow{4}{*}{ Piece } & Control & $70.25 \pm 1.12^{2) \mathrm{Aa} 3)}$ & $73.06 \pm 1.56^{\mathrm{Aa}}$ & $72.68 \pm 2.71^{\mathrm{Aa}}$ & $\mathrm{CT}^{4)}$ & $* * * 5)$ \\
\hline & & HHP-50 ${ }^{1)}$ & $69.82 \pm 2.04^{\mathrm{Aa}}$ & $69.98 \pm 3.49^{\mathrm{ABCa}}$ & $69.96 \pm 3.29^{\mathrm{Aa}}$ & $\mathrm{PC}$ & $* * *$ \\
\hline & & HHP-100 & $69.76 \pm 2.80^{\mathrm{Aa}}$ & $67.52 \pm 4.01^{\text {BCab }}$ & $62.60 \pm 3.60^{\mathrm{Bb}}$ & $\mathrm{BC}$ & $* *$ \\
\hline & & HНP-200 & $70.44 \pm 2.97^{\mathrm{Aa}}$ & $66.77 \pm 3.44^{\mathrm{Cab}}$ & $63.27 \pm 2.85^{\mathrm{Bb}}$ & \multirow{2}{*}{$\mathrm{CT} \times \mathrm{PC}$} & \multirow{2}{*}{$* * *$} \\
\hline & \multirow{4}{*}{ Shred } & Control & $71.49 \pm 1.09^{\mathrm{Aa}}$ & $71.71 \pm 2.41^{\mathrm{ABa}}$ & $64.15 \pm 2.60^{\mathrm{Bb}}$ & & \\
\hline & & HHP-50 & $48.30 \pm 2.54^{\mathrm{Ba}}$ & $46.08 \pm 1.58^{\mathrm{Da}}$ & $47.97 \pm 3.49^{\mathrm{Ca}}$ & $\mathrm{CT} \times \mathrm{BC}$ & NS \\
\hline & & HHP-100 & $44.12 \pm 1.98^{\mathrm{Ca}}$ & $41.54 \pm 1.48^{\mathrm{DEa}}$ & $43.27 \pm 2.78^{\mathrm{CDa}}$ & $\mathrm{PC} \times \mathrm{BC}$ & NS \\
\hline & & HHP-200 & $38.97 \pm 1.94^{\mathrm{Da}}$ & $38.94 \pm 1.43^{\mathrm{Ea}}$ & $39.04 \pm 1.89^{\mathrm{Da}}$ & $\mathrm{CT} \times \mathrm{PC} \times \mathrm{BC}$ & $* *$ \\
\hline \multirow{8}{*}{$\begin{array}{l}\text { Instrumental } \\
\text { firmness } \\
\left(\mathrm{kg}_{\mathrm{f}}\right)\end{array}$} & \multirow{4}{*}{ Piece } & Control & $0.53 \pm 0.06^{\mathrm{Aa}}$ & $0.53 \pm 0.05^{\mathrm{Aa}}$ & $0.55 \pm 0.05^{\mathrm{Aa}}$ & $\mathrm{CT}$ & $* *$ \\
\hline & & HHP-50 & $0.55 \pm 0.08^{\mathrm{Aa}}$ & $0.54 \pm 0.08^{\mathrm{Aa}}$ & $0.54 \pm 0.07^{\mathrm{Aa}}$ & $\mathrm{PC}$ & $*$ \\
\hline & & HHP-100 & $0.55 \pm 0.07^{\mathrm{Aa}}$ & $0.54 \pm 0.05^{\mathrm{Aa}}$ & $0.56 \pm 0.08^{\mathrm{Aa}}$ & $\mathrm{BC}$ & NS \\
\hline & & HНP-200 & $0.53 \pm 0.07^{\mathrm{Aa}}$ & $0.53 \pm 0.10^{\mathrm{Aa}}$ & $0.54 \pm 0.08^{\mathrm{Aa}}$ & \multirow{2}{*}{$\mathrm{CT} \times \mathrm{PC}$} & \multirow{2}{*}{ NS } \\
\hline & \multirow{4}{*}{ Shred } & Control & $0.53 \pm 0.07^{\mathrm{Aa}}$ & $0.52 \pm 0.09^{\mathrm{Aa}}$ & $0.52 \pm 0.08^{\mathrm{Aa}}$ & & \\
\hline & & HНP-50 & $0.60 \pm 0.05^{\mathrm{Aa}}$ & $0.60 \pm 0.03^{\mathrm{Aa}}$ & $0.61 \pm 0.08^{\mathrm{Aa}}$ & $\mathrm{CT} \times \mathrm{BC}$ & NS \\
\hline & & HHP-100 & $0.64 \pm 0.09^{\mathrm{Aa}}$ & $0.63 \pm 0.04^{\mathrm{Aa}}$ & $0.63 \pm 0.04^{\mathrm{Aa}}$ & $\mathrm{PC} \times \mathrm{BC}$ & NS \\
\hline & & HHP-200 & $0.66 \pm 0.06^{\mathrm{Aa}}$ & $0.64 \pm 0.10^{\mathrm{Aa}}$ & $0.63 \pm 0.08^{\mathrm{Aa}}$ & $\mathrm{CT} \times \mathrm{PC} \times \mathrm{BC}$ & NS \\
\hline
\end{tabular}

${ }^{1)} \mathrm{HHP}-50,50 \mathrm{MPa}$ high-hydrostatic-pressure treatment for $5 \mathrm{~min}$; HHP-100, $100 \mathrm{MPa}$ high-hydrostatic-pressure treatment for 5 min; HHP-200, 200 $\mathrm{MPa}$ high-hydrostatic-pressure treatment for $5 \mathrm{~min}$.

${ }^{2)}$ Each value is mean \pm SD $(n=3)$.

${ }^{3}$ Mean values in the same column $\left({ }^{\mathrm{A}-\mathrm{E}}\right)$ or row $\left({ }^{\mathrm{a}, \mathrm{b}}\right)$ followed by different letters are significantly different according to Duncan's multiple range test $(\mathrm{p}<0.05)$.

${ }^{4)} \mathrm{CT}$, cabbage type; $\mathrm{PC}$, pressure condition; $\mathrm{BC}$, brine concentration.

${ }^{5}$ Level of significance: NS, not significant; ${ }^{*} \mathrm{p}<0.05 ;{ }^{* *} \mathrm{p}<0.01 ;{ }^{* * *} \mathrm{p}<0.001$.

나 낱장형 대조구의 경도 $0.53-0.55 \mathrm{~kg}_{\mathrm{f}}$ 와 비교하여 유의적 차이가 없었다(Table 3). 따라서 초고압 절임 시 $50-200 \mathrm{MPa}$ 압력과 $10-15 \%$ 염수 농도 조건은 낱장형 절임 배추의 경도 에 영향을 미치지 않는 것으로 판단된다. 한편, $10-15 \%$ 염수 로 절임한 절단형 HHP-50, HHP-100과 HHP-200 처리구의 경도는 0.60-0.66 $\mathrm{kg}_{\mathrm{f}}$ 로 나타나 압력 조건에 따른 유의적인 차이는 확인되지 않았지만, 절단형 대조구 또는 신선 배추 시 료에 비해 높은 경향을 보였다. 이러한 연구 결과는 일반적으 로 절임 배추는 삼투압에 의한 수분 손실로 세포벽이 겹쳐져 신선 배추에 비해 경도가 증가한다는 Song 등(2016)의 보고 와 유사하였다. 또한, Sila 등(2004)은 200-500 MPa 처리 후
절단형 당근 세포 밖으로 유출된 pectinmethylesterase가 pectin을 pectic acid와 methanol로 분해하고, pectic acid는 $\mathrm{Ca}^{2+}$ 와 pectin cross-linking을 형성함으로써 당근 조직 경도 가 증가한다고 보고하였다. Three-way ANOVA 실시한 결과 절임 배추의 백색도 값은 시료 형태, 염수 $\mathrm{NaCl}$ 농도와 초고 압 강도에 대한 삼원 상호작용 효과가 유의하게 나타났다 $(\mathrm{p}<0.01)$. 반면, 절임 배추 경도는 이원 또는 삼원 상호효과가 확인되지 않았다(Table 3).

\section{절임 배추의 조직학적 특성}

초고압 절임 후 절단형 배추 세포조직의 형태학적 변화를 
주사전자현미경을 이용하여 관찰한 결과는 Fig. 1에 나타내 었다. $15 \%$ 염수로 절임한 경우, 절단형 대조구는 세포벽 변 형과 손상 없이 세포 형태가 온전하게 유지되었으며, 신선 배 추와 유사한 세포 내부 빈공간과 세포 구조가 관찰되었다. 반 면 절단형 HHP-100 처리구와 HHP-200 처리구의 세포벽은 균열과 수축이 발생하여 형태 변형이 나타났다. 또한 절단형 HHP-50, HHP-100과 HHP-200 처리구는 세포 내부에 거친 표면이 확인되었는데, 이는 세포막 손상에 따라 세포 소기관 이 세포 내강에 부착된 것으로 판단된다.

초고압 절임 중 neutral red를 함유한 염수 침투에 따른 낱 장형과 절단형 배추 시료의 외관 색 변화는 Fig. 2 와 같다. 절단형 배추 시료는 염수 $\mathrm{NaCl}$ 농도에 상관없이 압력 강도가 높을수록 neutral red 침투에 의한 발색이 강하게 나타났다.
한편, 50-200 MPa 압력 조건에서 절임한 낱장형 배추 조직의 염수 침투 양상을 관찰한 결과, neutral red에 의한 발색이 줄 기 외곽 부분과 잎 부분에 주로 나타났다. 이러한 결과를 통 해 낱장형 배추의 줄기 중앙 부분은 외곽에 비해 염수 침투율 이 낮을 것으로 판단된다. Bao 등(2016)은 절단 배의 초고압 처리 시 압력 강도와 세포벽 및 조직 손상도가 높은 상관관계 를 보였다고 보고하였다. 또한, Gonzalez 등(2010)은 50-600 $\mathrm{MPa}$ 초고압 처리한 슬라이스 양파의 조직학적 특성을 분석한 결과, $300 \mathrm{MPa}$ 이상 가압 처리로 양파의 세포막 membrane integrity가 완전히 상실되었으며 양파 경도는 유의적으로 증 가하였다는 결과를 보고하였다.

본 연구 결과, 대기압 조건과 비교하여 $50-200 \mathrm{MPa}$ 초고 압 절임한 배추가 높은 염도, 전기전도도, water loss와 solid

$15 \%$ brine salting treatment
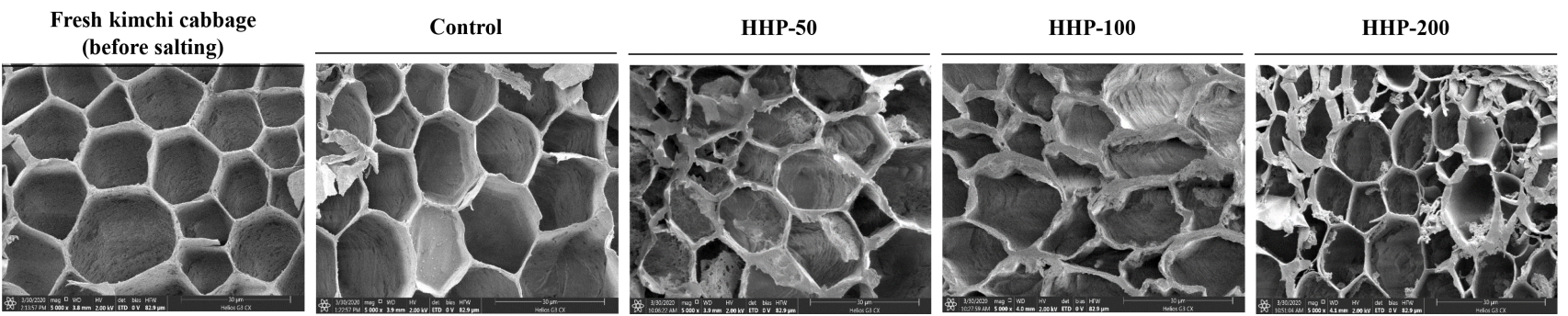

Fig. 1. Cross-sectional scanning electron microscope images of kimchi cabbage before and after salting under high-hydrostatic-pressure conditions. Magnification was $\times 5,000$ and the scale bar indicated $30 \mu \mathrm{m}$.

(A)

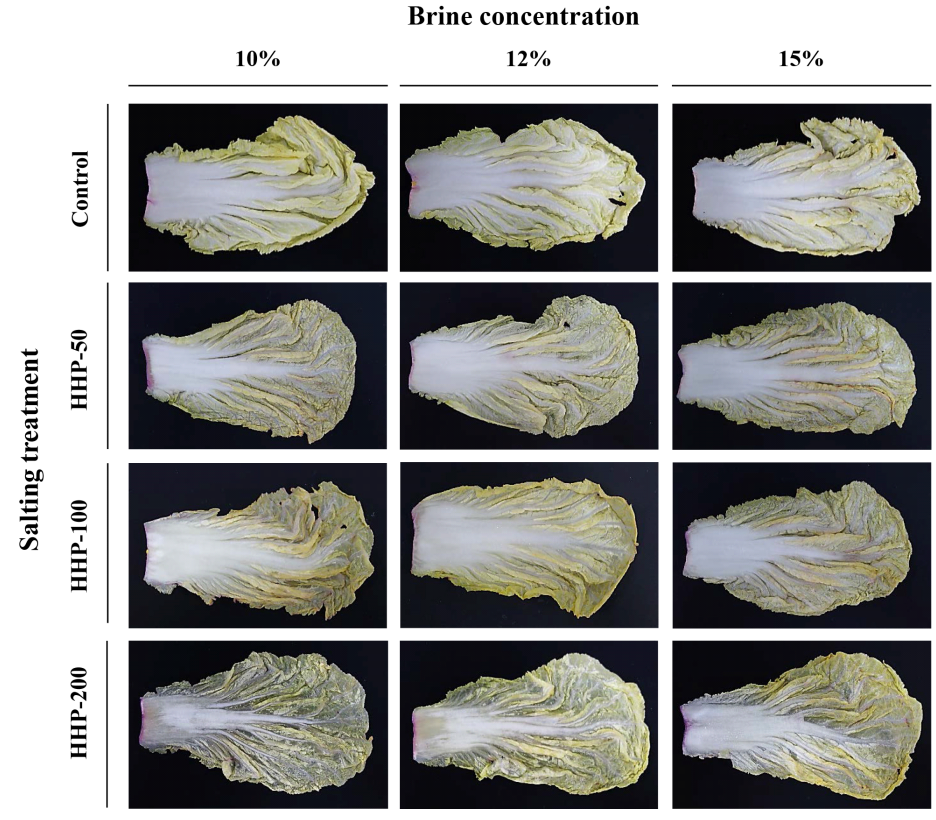

(B)

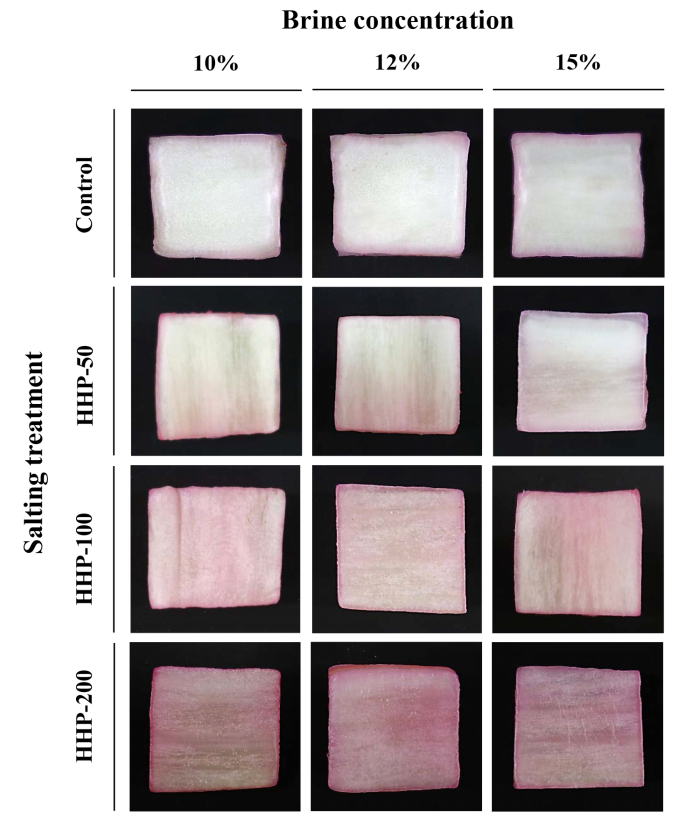

Fig. 2. Appearances of piece-type (A) and shred-type (B) kimchi cabbage after salting using 10, 12, and $15 \%$ brines containing neutral red under high-hydrostatic-pressure conditions. 
gain을 나타내었는데, 이는 초고압 환경이 배추 세포 구조와 형태를 변화시켜 염수의 용질인 $\mathrm{NaCl}$ 이 세포조직 안으로 쉽 게 침투할 수 있었기 때문으로 판단된다. 또한, 낱장형 절임 배추 외관과 백색도 변화를 고려하면 초고압 절임 시 50-100 $\mathrm{MPa}$ 압력과 $10-12 \%$ 염수 농도 범위 내 조건이 바람직할 것 으로 보인다.

\section{요 약}

본 연구는 50-200 MPa 초고압 조건에서 10-15\% 염수를 이용하여 5 분 절임한 낱장형과 절단형 배추의 이화학적 품질 과 미세 구조 변화를 분석하였다. 절임 후 낱장형과 절단형 배추의 염도와 전기전도도는 초고압 강도와 염수 $\mathrm{NaCl}$ 농도 가 증가할수록 유의적으로 $(\mathrm{p}<0.05)$ 높은 값을 나타냈다. 특 히 $15 \%$ 염수에서 절임한 절단형 HHP-200 처리구의 염도와 전기전도도는 $2.52 \%$ 와 $36.25 \mathrm{~S} / \mathrm{m}$ 로 각각 나타나, 절단형 대 조구와 비교하여 2.8과 2.3배 각각 높았다. 절임 후 낱장형과 절단형 배추 시료의 water loss와 solid gain 변화는 시료 형 태, 초고압 강도와 염수 $\mathrm{NaCl}$ 농도 요인의 삼원 상호작용 효 과가 유의하였다. $10 \%$ 염수에서 절임한 낱장형 대조구의 수 분함량은 $91.50 \%$ 로 절임 전 신선 배추 시료(91.65\%)와 유사 하였으나, $15 \%$ 염수에서 절임한 HHP-200 처리구의 수분함 량은 $88.52 \%$ 까지 감소하였다. $10 \%$ 염수로 절임한 낱장형 HHP-50, HHP-100과 HHP-200 처리구의 백색도 값은 69.82-70.44로 대조구와 비교하여 유의적 차이가 없었다. 반 면, $15 \%$ 염수로 절임한 절단형 대조구와 HHP-200 처리구의 백색도 값은 64.15 와 39.04 로 각각 나타나 뚜렷한 차이를 보 였다. 12 와 $15 \%$ 염수로 절임한 낱장형과 절단형 시료의 경 우, 경도는 대조구, HHP-50, HHP-100과 HHP-200 처리구 간의 유의적 차이는 보이지 않았다. 초고압 절임한 배추 조직 에서 구조적 변형 및 손상이 관찰되었으며, 이로 인해 세포 안으로 neutral red를 포함한 염수의 침투가 빠르게 진행된 것으로 확인하였다. 본 연구 결과를 종합하여 볼 때 초고압 절임은 절임 배추의 제조공정 중 배추 탈수와 염도 부여를 위한 염수 침지 소요시간을 단축하는데 활용할 수 있는 방법 이다. 향후 김치산업체 현장 적용을 위한 pilot-scale 초고압 절임 시스템 개발과 절임 조건 최적화 연구가 추가적으로 필 요하다.

\section{감사의 글}

본 연구는 2020년 농촌진흥청 공동연구사업(과제번호: PJ 0134042020)의 지원에 의해 이루어진 것으로 감사드립니다.

\section{Conflict of interests}

The authors declare no potential conflict of interest.

\section{ORCID}

Eun Ji Choi https://orcid.org/0000-0002-1725-4344

Ho Hyun Chun https://orcid.org/0000-0002-4937-9010

\section{References}

Bao R, Fan A, Hu X, Liao X, Chen F. Effects of high pressure processing on the quality of pickled radish during refrigerated storage. Innovative Food Sci Emerging Technol, 38, 206-212 (2016)

Cheon H, Lim T, Cho WI, Hwang KT. Textural characteristics and bacterial reduction in glutinous rice and brown rice pretreated with ultra-high pressure. Korean J Food Sci Technol, 48, 92-95 (2016)

Choi EJ, Chung YB, Han AR, Chun HH. Combined effects of sanitizer mixture and antimicrobial ice for improving microbial quality of salted Chinese cabbage during low temperature storage. J Korean Soc Food Sci Nutr, 44, 1715-1724 (2015a)

Choi EJ, Jeong MC, $\mathrm{Ku} \mathrm{KH}$. Effect of seasonal cabbage cultivar (Brassica rapa L. ssp. pekinesis) on the quality characteristics of salted-Kimchi cabbages during storage period. Korean J Food Preserv, 22, 303-313 (2015b)

Choi GH, Lee GY, Bong YJ, Jeong JK, Moon SH, Park KY. Comparison of quality properties of brined baechu cabbage manufactured by different salting methods and with different salts. J Korean Soc Food Sci Nutr, 43, 1036-1041 (2014)

Choi KH, Kim SI, Lee DU, Jeon JT. Effect of shelf-life extension of birch sap using high pressure processing. Korean J Food Preserv, 24, 343-350 (2017)

Dash KK, Balasubramaniam VM, Kamat S. High pressure assisted osmotic dehydrated ginger slices. J Food Eng, 247, 19-29 (2019)

Duguay AJ, Ramaswamy HS, Zareifard MR, Zhu S, Grabowski S, Marcotte M. Electrical conductivity of cabbage and daikon radish as affected by electrical voltage, frequency, salt concentration and temperature. J Food Process Eng, 40, e12315 (2017) 
Gonzalez ME, Jernstedt JA, Slaughter DC, Barrett DM. Influence of cell integrity on textural properties of raw, high pressure, and thermally processed onions. J Food Sci, 75, E409-E416 (2010)

Han GJ, Choi HS, Lee SM, Lee EJ, Park SE, Park KY. Addition of starters in pasteurized brined baechu cabbage increased kimchi quality and health functionality. J Korean Soc Food Sci Nutr, 40, 110-115 (2011)

Ha SJ, Yang SK, In YW, Kim YJ, Oh SW. Changes in microbial and physicochemical properties of single-brewed Makgeolli by high hydrostatic pressure treatment during fermentation. J Korean Soc Food Sci Nutr, 41, 11761181 (2012)

Huang HW, Hsu CP, Wang CY. Healthy expectations of high hydrostatic pressure treatment in food processing industry. J Food Drug Anal, 28, 1-13 (2019)

Jeong JW, Park SS, Lim JH, Park KJ, Kim BK, Sung JM. Quality characteristics of Chinese cabbage with different salting conditions using electrolyzed water. J Korean Soc Food Sci Nutr, 40, 1743-1749 (2011)

Kim HW, Jang JJ, Kim NH, Lee NY, Cho TJ, Kim SH, Rhee MS. Factors that determine the microbiological quality of ready-to-use salted napa cabbage (Brassica pekinensis): Season and distribution temperature. Food Control, 87, 1-8 (2018)

Kim NH, Jang SH, Kim SH, Lee HJ, Kim Y, Ryu JH, Rhee MS. Use of phytic acid and hyper-salting to eliminate Escherichia coli O157:H7 from napa cabbage for kimchi production in a commercial plant. Int J Food Microbiol, 214, 24-30 (2015)

$\mathrm{Ku} \mathrm{KH}$, Jeong MC, Chung SK. Industrialization of salted Chinese cabbages and fresh-cut Chinese cabbage. Food Science and Industry, 46, 2-11 (2013)

Lee MH, Lee GD, Son KJ, Yoon SR, Kim JS, Kwon JH. Changes in organoleptic and rheological properties of Chinese cabbage with salting condition. J Korean Soc Food Sci Nutr, 31, 417-422 (2002)

Lee MK, Yang HJ, Woo HN, Rhee YK, Moon SW. Changes in the texture and salt content of Chinese cabbage using different salting methods. J Korean Soc Food Sci Nutr, 40, 1184-1188 (2011)

Lee SH. Antioxidant capacity and nutritive components from biji sub-micron suspension by ultra-high pressure homogenization process. Korean J Food Preserv, 22, 714-720
(2015)

Maitland JE, Boyer RR, Eifert JD, Williams RC. High hydrostatic pressure processing reduces Salmonella enterica serovars in diced and whole tomatoes. Int $\mathrm{J}$ Food Microbiol, 149, 113-117 (2011)

Nunez-Mancilla Y, Perez-Won M, Uribe E, Vega-Galvez A, Scala KD. Osmotic dehydration under high hydrostatic pressure: Effects on antioxidant activity, total phenolics compounds, vitamin C and colour of strawberry (Fragaria vesca). LWT-Food Sci Technol, 52, 151-156 (2013)

O'Neill CM, Cruz-Romero MC, Duffy G, Kerry JP. Improving marinade absorption and shelf life of vacuum packed marinated pork chops through the application of high pressure processing as a hurdle. Food Packaging Shelf Life, 21, 100350 (2019)

Park SJ, Park DS, Lee SB, He XL, Ahn JH, Yoon WB, Lee HY. Enhancement of antioxidant activities of Codonopsis lanceolata and fermented Codonopsis lanceolata by ultra high pressure extraction. J Korean Soc Food Sci Nutrn, 39, 1898-1902 (2010)

Park SS, Sung JM, Jeong JW, Park KJ, Lim JH. Quality changes of salted Chinese cabbages with electrolyzed water washing and a low storage temperature. J Korean Soc Food Sci Nutr, 42, 615-620 (2013)

Rastogi NK, Angersbach A, Knorr D. Synergistic effect of high hydrostatic pressure pretreatment and osmotic stress on mass transfer during osmotic dehydration. J Food Eng, 45, 25-31 (2000)

Rux G, Gelewsky R, Schluter O, Herppich WB. High hydrostatic pressure effects on membrane-related quality parameters of fresh radish tubers. Postharvest Biol Technol, 151, 1-9 (2019)

Shim YH, Ahn GJ, Yoo CH. Characterization of salted Chinese cabbage in relation to salt content, temperature and time. Korean J Food Cook Sci, 19, 210-215 (2003)

Sila DN, Smout C, Vu TS, Hendrickx ME. Effects of highpressure pretreatment and calcium soaking on the texture degradation kinetics of carrots during thermal processing. J Food Sci, 69, E205-E211 (2004)

Song HY, Cheon SH, Yoo SR, Chung YB, Seo HY. Changes in quality characteristics of salted Kimchi cabbage and kimchi paste during storage. Korean J Food Preserv, 23, 459-470 (2016)

Taiwo KA, Eshtiaghi MN, Ade-Omowaye BIO, Knorr D. 
Osmotic dehydration of strawberry halves: influence of osmotic agents and pretreatment methods on mass transfer and product characteristics. Int J Food Sci Technol, 38, 693-707 (2003)

Verma D, Kaushik N, Rao PS. Application of high hydrostatic pressure as a pretreatment for osmotic dehydration of banana slices (Musa cavendishii) finish-dried by dehu- midified air drying. Food Bioprocess Technol, 7, 12811297 (2014)

Wang Z, Wei T, Zhang M. Effects of vacuum and normal pressure impregnation on water loss and solid gain of apple (Malus pumila Mill). J Food Process Preserv, 39, 1045-1050 (2015) 